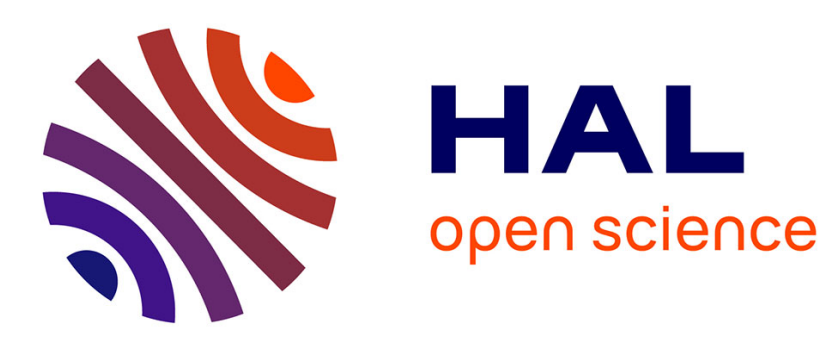

\title{
Using a furrow system for surface drainage under unsteady rain
}

\author{
A. Taky, J.C. Mailhol, Gilles Belaud
}

\section{To cite this version:}

A. Taky, J.C. Mailhol, Gilles Belaud. Using a furrow system for surface drainage under unsteady rain. Agricultural Water Management, 2009, 96 (7), p. 1128 - p. 1136. 10.1016/j.agwat.2009.02.014 . hal-00623059

\section{HAL Id: hal-00623059 \\ https://hal.science/hal-00623059}

Submitted on 13 Sep 2011

HAL is a multi-disciplinary open access archive for the deposit and dissemination of scientific research documents, whether they are published or not. The documents may come from teaching and research institutions in France or abroad, or from public or private research centers.
L'archive ouverte pluridisciplinaire HAL, est destinée au dépôt et à la diffusion de documents scientifiques de niveau recherche, publiés ou non, émanant des établissements d'enseignement et de recherche français ou étrangers, des laboratoires publics ou privés. 
Author-produced version of the article published in Agricultural Water Management, 2009, 96 (7),1128-1136. The original publication is available at http://www.sciencedirect.com/science/article/pii/S0378377409000596 doi:10.1016/j.agwat.2009.02.014

\title{
Using a furrow system for surface drainage under unsteady rain
}

\author{
A. Taky ${ }^{1}$, J.C, Mailhol ${ }^{2}{ }^{*}$, G. Belaud ${ }^{3}$ \\ ${ }^{1}$ Office Régional de Mise en Valeur Agricole du Gharb (ORMVAG), Kenitra \\ Morocco ${ }^{2}$ Cemagref, UMR G-EAU, BP 5095, 34160 Montpellier cedex 05 France \\ ${ }^{3}$ Institut de Recherche pour le Développement, UMR G-EAU, Maison des sciences de \\ l'eau 300 Av E. Jeanbrau, 34095 Montpellier Cedex 05, France
}

\begin{abstract}
Water excess during winter limits crop development on heavy clay soil conditions of the Gharb valley (Morocco). The furrow system to eliminate these negative effects is the adopted solution. This article focuses on the development of a water transfer model through a furrow system during unsteady rainfall event to evaluate the runoff volume resulting from a reference rainy event. This model contains a production function associated to a transfer function. The production function is based on the Green-Ampt infiltration equation. The latter has been adapted to account for unsteady rain conditions and rainfall intermittence. The transfer function is based on the kinematic wave model, the explicit solution of which is coupled with the water excess generated by the production function. Simulated runoff in the furrows is collected by a drainage ditch evacuating the flow outside a plot of 1.3 ha. The similarity between parameters of a furrow irrigation model and those of the production function is advantageously used for model calibration.

The proposed modelling approach shows capabilities to predict water amount and peak discharges evacuated from a plot of around 1 ha by a furrow system under unsteady rainfall events. As an application, it is used to evaluate the ability of the surface drainage system to evacuate the excessive volumes of water under typical rainfalls.
\end{abstract}

Key words: Runoff, furrow system, unsteady rainfall, overland flow, kinematic wave model. List of symbols

$A$ : wetted area in the furrow $\left(\mathrm{m}^{2}\right)$

$A^{\prime}:$ derivative of $A$ with respect to $Y\left(A^{\prime}=\mathrm{d} A / \mathrm{d} Y\right)$

$a:$ parameter of the Montana equation $\left(\mathrm{m} / \mathrm{s}^{\mathrm{b}}\right)$

$b$ : parameter of the Montana equation (-)

$C E$ : coefficient of efficiency (-)

$D$ : characteristic duration of the one year return period rainfall (s)

$d t:$ time step in the transfer model (s)

$d x:$ space step in the transfer model $(\mathrm{m})$

$h:$ capillary suction $(\mathrm{m})$

$h_{i}$ : initial capillary suction $(\mathrm{m})$

$h_{f}:$ the capillary suction at the wetting front $(\mathrm{m})$

$F L$ : furrow length $(\mathrm{m})$

$f_{s}$ : inter-furrow spacing (m)

$I$ : cumulative infiltration during a rainy event $(\mathrm{m})$

$I^{k}$ : cumulative infiltration $(\mathrm{m})$ during the rainfall event $k$

\footnotetext{
* Corresponding author. Tel.: +33 467 046346; fax: +33 467166440.

E-mail address: jean-claudemailhol@cemagref.fr (J.C. Mailhol).
} 
Author-produced version of the article published in Agricultural Water Management, 2009, 96 (7),1128-1136. The original publication is available at http://www.sciencedirect.com/science/article/pii/S0378377409000596 doi:10.1016/j.agwat.2009.02.014

$I_{f}:$ cumulative infiltration during furrow irrigation $(\mathrm{m})$

$I_{r p}:$ cumulated rainfall $(\mathrm{m})$

$J$ : the friction slope $(\mathrm{m} / \mathrm{m})$

$k$ : rainfall event number

$K_{s}:$ saturated conductivity $(\mathrm{m} / \mathrm{s})$

$L_{f}$ : length of the infiltration front $(\mathrm{m})$

$m:$ wall slope of the furrows (-)

$n$ : roughness coefficient $\left(\mathrm{s} / \mathrm{m}^{1 / 3}\right)$

$N$ : number of furrows

$P:$ wetted perimeter $(\mathrm{m})$

$P_{1}$ : cumulative rainfall for the one year return period $(\mathrm{mm})$

$q:$ infiltration rate $(\mathrm{m} / \mathrm{s})$

$q_{c}:$ infiltration capacity $(\mathrm{m} / \mathrm{s})$

$q_{r}:$ rainfall intensity $(\mathrm{m} / \mathrm{s})$

$Q$ : flow rate in the furrow during runoff $\left(\mathrm{m}^{3} / \mathrm{s}\right)$

$Q^{\prime}$ : derivative $Q$ with respect to $Y\left(Q^{\prime}=\mathrm{d} Q / \mathrm{d} Y\right)$

$Q_{p}$ : peak discharge $\left(\mathrm{m}^{3} / \mathrm{s}\right)$

$R: \operatorname{runoff}(\mathrm{m} / \mathrm{s})$

$r=R f_{S}$ : lateral contribution due to runoff on a width $f_{S}\left(\mathrm{~m}^{2} / \mathrm{s}\right)$,

$R_{h}$ : hydraulic radius (m)

$S_{0}:$ field slope $(\mathrm{m} / \mathrm{m})$

$t$ : current time (s)

$T_{a}(x)$ : advance time of the water front during an irrigation event (s)

$t_{B}$ : time of rain event beginning (s)

$t_{B}{ }^{k}$ : time when the $k$-th rainfall event begins (s)

$t_{E}{ }^{k}$ : time when the $k$-th rainfall event stops (s)

$t_{p}$ : ponding time (s)

$x$ : furrow abscissa $(\mathrm{m})$

$Y$ : water depth $(\mathrm{m})$ :

$Z_{r}:$ a reference soil depth $(1 \mathrm{~m})$

$\alpha$ : parameter of the $K(h)$ equation $\left(\mathrm{m}^{-1}\right)$

$\beta$ : parameter of the soil water depletion function

$\lambda_{c}$ : capillary length $(\mathrm{m})$

$\chi$ : parameter ruling the macro pore effect in the irrigation model

$\Delta \theta:$ saturation deficit

$\Delta t$ : calculation time step ( $\mathrm{s})$

$\Delta x$ : calculation space step $(\mathrm{m})$

$\theta:$ water content $\left(\mathrm{cm}^{3} / \mathrm{cm}^{3}\right)$

$\theta_{B}{ }^{k}$ : water content $\left(\mathrm{cm}^{3} / \mathrm{cm}^{3}\right)$ at the beginning of the rainfall event $\mathrm{k}$

$\theta_{E}{ }^{k}$ : water content $\left(\mathrm{cm}^{3} / \mathrm{cm}^{3}\right)$ at the end of the rainfall event $\mathrm{k}$

$\theta_{s}:$ saturated water content $\left(\mathrm{cm}^{3} / \mathrm{cm}^{3}\right)$

$\theta_{f c}$ : water content at field capacity $\left(\mathrm{cm}^{3} / \mathrm{cm}^{3}\right)$

$\theta_{i}$ : initial water content $\left(\mathrm{cm}^{3} / \mathrm{cm}^{3}\right)$

$\sigma:$ a shape parameter of the furrow $\sigma=\left(1+m^{2}\right)^{1 / 2}$

$\tau$ : current time between $-D$ and $+D$ in the one year return period rainfall formulation (s)

Note: Numerical values of variables may be given in different units in the text and figures. 


\section{Introduction}

Rainfall excess on the heavy clayey soils of the Gharb valley (Morocco) strongly limits the production of crops sown during winter. The subsurface drainage system, the main role of which is to maintain the level of the saline groundwater deep enough, does not allow a complete and fast evacuation of this water excess (Bouarfa and Zimmer, 2000), due to the absence or degradation of land levelling. Considering energy costs and maintenance problems, sprinkler irrigation has often been replaced by traditional surface irrigation (Mailhol et al., 1999).

Impacts of water excess during winter on crop growing in unlevelled plots are clearly shown in Taky et al. (2005). This work also highlights the beneficial role of a furrow system on crop production (sugar beet) for both experimental and farmer plots. To encourage farmers adopting modern surface irrigation systems, furrow irrigation tests were conducted on 180 to $240 \mathrm{~m}$ long laser levelled plots, and water was supplied using siphons, floppy pipes or rigid gated pipes The furrow system, designed for water supply during the irrigation season, also allows the evacuation of excessive rainfall amounts during winter.

The objective of this article is to present a numerical model allowing a runoff prediction within a furrow system submitted to complex rainfall events. Overland flow modelling under constant rain intensities has been addressed by several researchers using a two dimensional approach (Chow and Ben-Zvi, 1973; Zhang and Cundy, 1989; Taylor et al., 1993). More recently Esteves et al. (2000) proposed a comparable approach for complex rainfall events. Their overland flow model results from a coupling of the Green-Ampt infiltration solution with the Saint-Venant solution used for the surface transport.

The previous studies all refer to small-scale plots of a few square-meters. At this scale, runoff is subject to micro topography and a 2D-modelling approach is required for the surface water transport. Muños-Carpena et al. (1998) also used the Green-Ampt model coupled with the kinematic wave model for sediment transport simulation in vegetative filter strips. Paige et al. (2002) used a similar modelling approach with a rainfall simulator and analyzed the sensitivity of the runoff response to the rainfall rate. These two latter researches refer to a plane surface and the kinematic wave solution is not described.

Although soil properties of the experimental plot are assumed to be spatially constant, the originality of the present work is to propose a runoff transfer model through a furrow system model applicable at a plot scale of around 1 hectare. In addition, the production function is based on an infiltration model that uses the same parameters as the ones used to simulate the furrow irrigation. This runoff model is a useful tool to design the ditches for the runoff evacuation of a whole system of furrow irrigated plots. It could be considered as a component of a future integrated modelling approach for simulating furrow irrigation practices at the plot and season scale in the Gharb valley.

\section{Model development}

The hydrological model consists of a production function generating a water excess at the scale of an elementary sub-plot (Fig.1) coupled with an overland flow model transferring the water excess through a furrow system. The simulated plot is composed of $N$ furrows of length $F L$. These furrows outflow in a ditch at the extremity of which was installed an automatic gauge station (Fig. 2).

\subsection{Production function}

The production function calculates the water excess at the scale of the elementary sub-plot of width $f_{s}=1.5 \mathrm{~m}$ (furrow spacing) and of length $d x$, the transfer space step. This water excess 
is assumed to instantaneously supply a furrow element. Since water heights within the furrows are generally low, infiltration along their walls can be neglected. Consequently, infiltration will be globally considered as being governed by a 1D process. This production function needs to manage intermittent rainfall. A rainfall episode, the duration of which can be of one or two days, constitutes continuous rainfall events at different rates separated by no rain periods. For an unsteady rain event, there may exist different periods during which rainfall rate is greater than infiltration capacity. Under such circumstances, several ponding times can be generated while there is at most one ponding time under steady rain conditions.

This production function uses the Green-Ampt infiltration model (Green and Ampt, 1911) as a simplified approach of the infiltration process. It assumes a homogenous soil profile and an initial water content $\theta_{i}$ uniformly distributed with depth. According to this model, the advancing front in the soil separates a saturated zone and a zone still at initial soil moisture. Mein and Larson (1973) and Swartzendruber (1974) used this model to describe ponded infiltration with constant intensity rainfall conditions. This model was also applied under unsteady conditions (Chu, 1978; Esteves et al., 2000). Muños-Carpena et al. (1998) also used the Green-Ampt approach with the method of Chu (1978) to account for the water amount infiltrated before ponding. Paige et al. (2002) used a same modelling approach with a rainfall simulator and performed a sensitivity analysis of runoff response to the rainfall rate. They showed that runoff is sensitive to rainfall intensity and initial moisture content. They also showed that a unique hydraulic conductivity parameter is not sufficient to correctly simulate the runoff peak on a surface with bare soil and vegetation especially in case of high rainfall intensities. A significant improvement of the simulations was obtained on the basis of a strip model configuration after tuning a second effective conductivity.

\subsubsection{Runoff production during a rainfall event}

Infiltration is composed of two stages. As described by Mein and Larson (1973), when the rain intensity $q_{r}$ is lower than infiltration capacity $q_{c}$, all the rain infiltrates into the soil and actual infiltration rate $q$ is equal to $q_{r}$. Cumulative infiltration $I$ is equal to cumulative rain $I_{r p}$. This is valid as long as the rain intensity is lower than the infiltration capacity $q_{c}$. To calculate the infiltration capacity, the Green-Ampt approach is used, where the ponding time $t_{p}$ is the time at which $q=q_{r}=q_{c}$. According to Green-Ampt's model, the depth of the saturated zone (in which $\theta=\theta_{s}$ ) is given by

$$
L_{f}=I_{r p} / \Delta \theta
$$

where $L_{f}$ is the position of the wetting front, $\Delta \theta=\theta_{s}-\theta_{i}$ is saturation deficit (saturation moisture minus initial moisture) and $I_{r p}$ is the cumulated rainfall from the rain event beginning $\left(t_{B}\right)$ until the ponding time. The application of the Darcy's equation gives the infiltration capacity for ponded conditions:

$$
q_{c}=K_{s}+K_{s} \frac{\left|h_{f}\right|}{L_{f}}
$$

where $K_{s}$ is saturated conductivity and $h_{f}$ is the capillary suction at the wetting front. After ponding $\left(t>t_{p}\right)$, infiltration $q$ equals infiltration capacity $q_{c}$ and the cumulative infiltration is calculated as follows:

$$
I=I_{r p}+\int_{t_{p}}^{t} q_{c}(t) d t
$$

The infiltration capacity is calculated according to Eq. (2) in which the wetting front position is given by

$$
L_{f}=I / \Delta \theta
$$


A similar approach was used by Chu (1978) who integrates Eq. (3) and gets a relation between $I$ and $t$. A numerical method is required to determine $I$ then its derivative $q$. Focussing on the infiltration rate $q$ (rather than the cumulative infiltration), it is more convenient to solve Eqs (2) and (4) at each calculation time step, which is done using an explicit numerical scheme.

Finally, runoff $R(t)$ is obtained by the difference between rain intensity and infiltration capacity:

$$
R(t)=q_{r}-q_{c}
$$

The water excess at the soil surface of the elementary sub-plot is assumed to be quasi instantaneously evacuated by the furrow system and consequently the resulting positive pressure head at the soil surface is not considered. Saturated conductivity $K_{s}$ is assumed constant and not affected by the rainfall rate, the air entrapment phenomenon not being considered here.

\subsubsection{Soil parameters}

A physical signification of $h_{f}$ has been proposed by some authors. Newman (1976), for instance, has shown that

$$
h_{f}=\frac{1}{K_{S}} \int_{0}^{h_{i}} K(h) d h
$$

,where $h_{i}$ is initial capillary suction.

In the frame of the validity of the Green-Ampt model [the delta Soil as defined by Philip (1957; 1973)] $h_{f} \approx-\lambda_{c}$ (capillary length) using the Gardner function, where saturated conductivity is assumed to increase exponentially with $h$ (Gardner, 1958):

$$
K(h)=K_{s} \exp (\alpha h)
$$

The value of $\alpha^{-1}=\lambda_{c}$ is the macroscopic capillary length scale (Philip, 1984; White and Sully, 1987; Thony et al., 1991) which is a hydraulic characteristic of the soil. From a physical point of view $\lambda_{c}$ represents the average height of the capillary fringe. It is numerically equivalent to the soil water pressure head $\left|h_{f}\right|$ at the wetting front (Kutilek and Nielsen, 1994). It varies from 3 to $5 \mathrm{~cm}$ for sand to $25 \mathrm{~cm}$ (White and Sully, 1987) and more for clay (Kutilek and Nielsen, 1994; Mailhol, 2003).

\subsubsection{A new procedure to account for rainfall intermittence}

When the rainfall stops, the soil water depletion phase starts. Its duration depends on the occurrence date of the next rainfall event. The soil moisture conditions for predicting the infiltration capacity of the subsequent rainfall event need to be updated. Since the rain duration is quite short, generally less than one day, evapotranspiration is neglected. Denoting $t_{B}{ }^{k}$ the time when the $k$-th rainfall event begins, $t_{E}{ }^{k}$ when it stops; the corresponding soil moistures are denoted $\theta_{B}{ }^{k}$ and $\theta_{E}{ }^{k}$. At the end of the rainfall event $k$, averaged soil water content on a reference depth $Z_{r}$ is given by:

$$
\theta_{E}{ }^{k}=\theta_{B}{ }^{k}+I^{k} / Z_{r}
$$

where $I^{k}=$ cumulative infiltration (m) during the rainfall event $k$ and $Z_{r}$ is the reference soil depth (m). A reference soil depth $Z_{r}=1 \mathrm{~m}$ is assumed to be a valuable depth to account for Hortonian infiltration processes under high clayey soil conditions. At the beginning of the depletion stage $\left(t \geq t_{E}^{k}\right)$, soil water content decreases rapidly from $\theta(t)=\theta_{E}^{k}\left(\theta_{E}^{k} \leq \theta_{s}\right)$ until it reaches the field capacity, then the depletion is much slower (Marcesse, 1967). The soil water content at field capacity is denoted $\theta_{f c}$. Because runoff is specific to the winter period, where 
$\theta$ is usually greater than $\theta_{f c}$, the first depletion phase will be only considered. The depletion process is simulated as follows:

$$
\theta(t)=\theta_{f c}+\left(\theta_{E}^{k}-\theta_{f c}\right) \exp \left[-\beta\left(t-t_{E}^{k}\right)\right] \quad,
$$

in which $\beta$ is an empirical coefficient depending on soil properties and soil conditions. Its value reflects the velocity at which the soil drains. At the beginning of the next rainfall event $k+1$, the soil water content is equal to $\theta_{B}{ }^{k+1}=\theta_{f c}+\left(\theta_{E}{ }^{k}-\theta_{f c}\right) \exp \left[-\beta\left(t_{B}{ }^{k+1}-t_{E}{ }^{k}\right)\right]$. From this moisture, the infiltration capacity at the beginning of rainfall event $(k+1)$ is calculated according to Eqs (1) and (2).

\subsection{Transfer model}

\subsubsection{Model equations}

The slope of the furrows is generally greater than $0.1 \%$. In this range, the kinematic wave model is a good approximation of the Saint-Venant's transfer equations (Woodhiser and Liggett, 1967) for the runoff generated by each elementary sub-plot. This model is often used to simulate the advancing front in furrow irrigation (Walker and Humpherys, 1983) but with different boundary conditions.

The kinematic wave solution combines the following set of equations:

$$
\begin{aligned}
& \frac{\partial A}{\partial t}=\frac{\partial Q}{\partial x}=r \\
& S_{0}=J=n^{2} \frac{Q^{2}}{A^{2} R_{h}^{2 / 3}}
\end{aligned}
$$

where $A$ is the wetted area in the furrow $\left(\mathrm{m}^{2}\right), t$ the current time (s), $Q$ the discharge in the furrow $\left(\mathrm{m}^{3} / \mathrm{s}\right), r=R f_{S}$ the lateral contribution due to runoff on a width $f_{S}\left(\mathrm{~m}^{2} / \mathrm{s}\right), S_{0}$ the furrow slope $(\mathrm{m} / \mathrm{m}), J$ the friction slope, $n$ the Manning roughness coefficient $\left(\mathrm{s} / \mathrm{m}^{1 / 3}\right)$ and $R_{h}$ is the hydraulic radius $(\mathrm{m})$ defined as $A / P(P=$ wetted perimeter $)$.

The boundary conditions are:

$$
\text { At } t=0, A(x, t)=0 \text { for all } x
$$

At the upstream end $(x=0), A=0$ for all $t$.

Each furrow supplies the ditch which conveys the whole flow out of the plot. Due to the depth of the ditch, a free drainage boundary condition is set at the furrow downstream end. The kinematic wave solution of Eqs $(10 \mathrm{a}, \mathrm{b})$ is also used for simulating the flow in the ditch, in which lateral contribution is the outlet discharge of each furrow. This set of equations is solved numerically according to an explicit scheme described below.

\subsubsection{Numerical solution}

The furrow is discretized with a constant length step $d x$. The simulation period is discretized with a time step $d t$. The discretized variables $A$ and $Q$ at the $i$-th space step and $j$-th time step are denoted $A_{i}^{j}$ and $Q_{i}^{j}$. The terms of Eq (10a) are approximated at the first order as follows:

$$
\begin{aligned}
& \frac{\partial A}{\partial t} \approx \frac{1}{2 d t}\left[\left(A_{i}^{n+1}-A_{i}^{n}\right)+\left(A_{i+1}^{n+1}-A_{i+1}^{n}\right)\right] \\
& \frac{\partial Q}{\partial x} \approx \frac{1}{2 d x}\left[\left(Q_{i+1}^{n}-Q_{i}^{n}\right)+\left(Q_{i+1}^{n+1}-Q_{i}^{n+1}\right)\right] \\
& r \approx \frac{1}{2}\left(r^{n+1}+r^{n}\right)
\end{aligned}
$$


At the $(n+1)$-th time step, the values at the $(i+1)$-th abscissa are searched as functions of the values in $i$ and those of the $n$-th time step. Two unknown terms need to be determined, $A_{i+1}^{n+1}$ and $Q_{i+1}^{n+1}$. The finite differences in the system of Eqs $(12 \mathrm{a}, \mathrm{b}, \mathrm{c})$ are replaced using the following first-order approximations, in which the unknown is the water depth $Y_{i+1}{ }^{n+1}$ :

$$
\begin{array}{ll}
A_{j}^{n+1}-A_{j}^{n} \approx\left(Y_{j}^{n+1}-Y_{j}^{n}\right) A_{j}^{\prime n}, & j=i, i+1, \\
Q_{i+1}^{k}-Q_{i}^{k} \approx\left(Y_{i+1}^{k}-Y_{i}^{k}\right) Q_{j}^{\prime k}, & k=n, n+1,
\end{array}
$$

(Delete the dots as multiplication sign in both equations)

in which $A^{\prime}$ and $Q$ ' denote the derivatives of $A$ and $Q$ with respect to the water depth $Y$. The calculation of $Q^{\prime}$ uses the Manning roughness formula (10b). The details of the calculation are given in appendix. Finally, replacing the partial derivatives in Eq. (10a) with the approximated finite differences leads to the following equation:

$$
Y_{i+1}^{n+1}\left[A_{i+1}^{\prime n}+\frac{d t}{d x} Q_{i}^{\prime n+1}\right]=Y_{i+1}^{n} A_{i+1}^{\prime n}-\left(Y_{i}^{n+1}-Y_{i}^{n}\right) A_{i}^{\prime n}+\frac{d t}{d x}\left[\left(Y_{i}^{n}-Y_{i+1}^{n}\right) Q_{i}^{\prime n}+Y_{i}^{n+1} Q_{i}^{\prime n+1}\right]+\left(r^{n+1}+r^{n}\right) d t
$$

which gives $Y_{i+1}^{n+1}$ explicitly. To avoid numerical instabilities, the Courant number, $\frac{Q \Delta t}{A \Delta x}$, of this explicit scheme should be close to 1 (Cunge et al., 1980).

\section{Field Experiments}

The studied plot belongs to an experimental station in the Gharb valley managed by ORMVAG (Kenitra, Morocco). The soil is mainly clayey (65-70\%) with sand (20-30\%). During summer it develops large cracks under high water deficit conditions (Mailhol et al., 1999). The plot was $230 \mathrm{~m}$ long and $50 \mathrm{~m}$ wide and was laser levelled with a slope $S_{0}=0.2 \%$.

Sugar beet was cultivated for two years: 2004-2005 and 2005-2006. For both, it was planted at mid November after a furrow ridging, then furrow irrigated. The furrow spacing $f s$ was $1.5 \mathrm{~m}$. Average furrow shape was trapezoidal with a side slope $m \approx 1 / 2$, and a bottom width and a maximal depth of $0.15 \mathrm{~m}$. At the extremity of the plot, runoff from furrows was collected by a trapezoidal ditch with a bottom width of $0.5 \mathrm{~m}$ and a slope of $0.25 \%$.

A complete meteorological station located on the experimental site recorded rainfall events thanks to an automatic rain-gauge system with a recording time step of $15 \mathrm{~min}$. To measure the outflow, a triangular flume equipped with an ultrasonic sensor was installed in November 2004 at the downstream end of the ditch. Instantaneous outlet discharges were automatically recorded at a time step of 15 min by a SAB600 (LMU) system supplied by an electrical solar panel.

Five significant runoff events (peak discharge $Q_{p} \geq 1 \mathrm{~L} / \mathrm{s}$ ) occurred and were monitored during the two seasons. Two events had a peak discharge close to $8 \mathrm{~L} / \mathrm{s}$ (March 2005, January 2006), a third one had a peak close to $4 \mathrm{~L} / \mathrm{s}$ (March 2006) while the $4^{\text {th }}$ (November 2004) and the $5^{\text {th }}$ (February 2006) had a peak of $2 \mathrm{~L} / \mathrm{s}$ and $1 \mathrm{~L} / \mathrm{s}$ respectively. For soil water content monitoring, two sites (upstream and downstream part of the plot) were equipped with two 30-cm CS6115 Cambell TDR probes inserted into the soil in the vicinity of the crop lines.

During the irrigation campaign of 2005, two irrigation events were monitored, on April $2^{\text {nd }}\left(3^{\text {rd }}\right.$ irrigation) and June $6^{\text {th }}$ ( $6^{\text {th }}$ irrigation $)$. Just before these two irrigation events, the soil water content profile was established by the gravimetric method on $1 \mathrm{~m}$ depth. Inlet discharge supplied by the gated pipe system was measured by means of trapezoidal flumes (RBC type) well adapted for low discharge (Walh et al., 2005). Total input discharge was controlled by a volumetric valve too. The advance trajectories of 18 furrows were monitored 
by determining the advance times $T_{a}$ at nine abscissas. This experimental setup allowed the calibration of the hydraulic characteristics of the soil.

\section{Model Calibration and Validation}

The model consists of a production function, which yields the volume of water drained out of the plot, and a transfer function that represents the propagation of the flow from the plot to the outlet. For the production function, five parameters need to be calibrated: $\theta_{s}, \theta_{i}, \beta, \lambda_{c}$, and $K_{s}$. These parameters are first calibrated, so that the model correctly represents the runoff volume. Some of these parameters are hydraulic characteristics of the soil and may be adjusted independently of the rainfall events. To this end, these parameters were calibrated on the irrigation events of April and June 2005. In a second step, the transfer function was calibrated so that it correctly represented the delay process within the drainage system. The transfer function introduces one more parameter, the Manning roughness coefficient. The surface flow conditions are rather different during furrow irrigation and during rainfall, and this Manning coefficient should be calibrated separately in each condition.

\subsection{Calibration during irrigation events}

The capillarity fringe $\lambda_{c}$ and the hydraulic conductivity $K_{s}$ are hydraulic characteristics of the soil that can be determined during irrigation events. To this end, we use the infiltration equation developed by Mailhol (2003) to simulate the furrow irrigation process:

$$
I_{f}(t)=0.9 \lambda_{c} \Delta \theta\left[1-\exp \left(\chi K_{s}\left(\lambda_{c} \Delta \theta\right)^{-1} t\right)\right]+K_{s} t
$$

where $\Delta \theta=\theta_{s}-\theta_{i}$ and $\chi$ is an empirical factor set at values greater than or equal to 80 for heavy cracking soils, and close to 10 without or under weak cracking soil conditions. Unlike the Green-Ampt equation, Eq. (15) enables to account for the role played by the macroporosity that can be quasi instantaneously filled by an important water amount (Mailhol and Gonzalez, 1993). The $\chi$ parameter indeed allows us to reduce or to increase the role of macroporosity in the infiltration process, giving thus more flexibility to the model. Parameters $\lambda_{c}$ and $K_{s}$ are involved in the exact analytical advance solution of the water balance equation. They are derived from the advance monitoring of an irrigation event by an inverse method (Mailhol, 2003; Mailhol et al., 2005).

Saturated soil water content $\theta_{s}=0.45$ was obtained from laboratory experiments during which the TDR calibration was performed by the method of Quinones et al. (2003). The initial soil moisture $\theta_{i}$ is measured (average value on $1 \mathrm{~m}$ depth) just before irrigation. The irrigation event of April 2005 is used for parameter calibration while that of June is used for parameter validation. The average discharge at the furrow head is $1.15 \mathrm{~L} / \mathrm{s}$ for both irrigations. For the downstream discharge (RBC flume measurements), the coefficient of variation is about $10 \%$. For the advance times $T_{a}(x)$, the coefficient of variation is between 7 and $17 \%$, which is consistent with the variation on the head discharges. Figure 3 a shows the calibration result on the advance trajectory $(T a)$ of the median furrow for a $\Delta \theta$ value of 0.18 , while Fig. $3 \mathrm{~b}$ presents the validation step for $\Delta \theta=0.20$. For both irrigation events, the roughness coefficient $n$ is set to 0.04 (Mailhol and Gonzalez, 1993; Mailhol, 2003; Mailhol et al., 2005). The derived parameters from the furrow irrigation model are $\overline{\lambda_{c}}=40 \mathrm{~cm}$ and $\overline{K_{s}}=0.3 \mathrm{~cm} / \mathrm{h}$. 
Author-produced version of the article published in Agricultural Water Management, 2009, 96 (7),1128-1136. The original publication is available at http://www.sciencedirect.com/science/article/pii/S0378377409000596 doi:10.1016/j.agwat.2009.02.014

\subsection{Model calibration during rainfalls}

The runoff event of March 2005 is used for model calibration, the other ones being used for model verification. The runoff of March 2005 event represents $7 \mathrm{~mm}$ out of a total rain of 21 $\mathrm{mm}$ fallen the $4^{\text {th }}$ of March in 10 hours, from 3 am to $1 \mathrm{pm}$. The events were simulated with a space step $d x=1.5 \mathrm{~m}$. The time step was set to $1 \mathrm{~s}$, which insured Courant number to be close to 1 . Since the rain depth is measured every $15 \mathrm{~min}$, the rain intensity is assumed constant during this time interval.

The calibration is composed of two steps. The first refers to the parameters of the production function while the second refers to $n$, the transfer model parameter. For the first step, the production function was disconnected from the transfer function. The parameters of the production function are set to the values obtained from irrigation monitoring. For the soil parameters, a value of $40 \mathrm{~cm}$ for $\lambda_{c}$ (assimilated to $-h_{f}$ in the Green-Ampt model) and $0.3 \mathrm{~cm} / \mathrm{h}$ for $K_{s}$ are adopted. Initial soil water content $\theta_{i}$ is derived from TDR measurements. The value which is taken into consideration corresponds to the beginning of the rainfall event initiating runoff. In March 2005, the value $\theta_{i}=0.43$ is obtained (Fig. 4), which is close to saturation. Parameter $\beta$, governing the fast drainage function, is obtained from the soil water depletion curve (Fig. 5) from the end of the considered rainy event. The following set of parameters is obtained: $\beta=0.00007, \theta_{i}=0.43, \lambda_{c}=40 \mathrm{~cm}, \mathrm{~K}_{\mathrm{s}}=0.3 \mathrm{~cm} / \mathrm{h}$. The corresponding simulations resulted in slightly under-estimated values of the runoff $(6 \mathrm{~mm}$ instead of $7 \mathrm{~mm})$. Indeed, infiltration process under furrow irrigation is different from that existing under a rainy event. Under furrow irrigation, water infiltrates the soil on the furrow surface, resulting in a 2D process, while infiltration occurs on the inter-furrow area during rainfalls. After tuning parameter $K_{s}$, a slight improvement was obtained with $K_{s}=0.2 \mathrm{~cm} / \mathrm{h}$ instead of $0.3 \mathrm{~cm} / \mathrm{h}$, the value derived from the furrow model. The difference in these $K_{s}$ values can result from a difference of the soil temperatures between winter and summer (or end of spring) according to Heasom et al. (2006), causing differences in water viscosity. For instance, for 2005, the daily average temperature of January is $8^{\circ} \mathrm{C}$ while that of May is $19^{\circ} \mathrm{C}$, causing the water viscosity to be 1.4 times lower in May than in June. This is consistent with variations of $K_{s}$.

In a second step, the transfer function was calibrated by tuning the Manning roughness coefficient. This coefficient should be different between irrigation conditions and rainfall ones. Indeed, the water depth is much lower during rainfalls than under furrow irrigation, the lumps in the furrows causing the relative roughness to be much higher in the case of rainfall. Also, the transfer model integrates the runoff on the elementary sub-plot partially covered by the crop as well as the runoff in the furrows. The calibration phase yields a value of $n=0.2$ during rainfall for all events. This value of $n$ is higher than the one usually observed in furrows, which is consistent with the remarks above. Comparable values but in the case of runoff on a plane surface with vegetation were found by Muñoz-Carpena et al. (1998), Paige et al. (2002), Mailhol and Merot (2008). In fact, surface conditions (roughness of the soil surface, crop height) can cause some variation of the roughness coefficient with time, affecting the transfer dynamics. Such a refinement could be addressed with a large number of rainfall events, but it is not significant in the present study. The sensitivity analysis presented further shows the influence of the Manning roughness parameter on the outflow hydrograph. The quality of the simulation is attested by the high values of the coefficient of efficiency of Nash-Sutcliffe (ASCE, 1993), denoted $C E$, obtained after model calibration (Fig. 6). A $C E$ value close to 1 indicates that predicted discharge is close to the measured one.

The other events are used for the validation step. For the rainy event of January 2006, the initial soil moisture is close to saturation $\left(\theta_{i}=0.43\right)$ at the beginning of the rain, causing the runoff process. Maximal discharge is well simulated, whereas the depletion phase is partially under-predicted (Fig. 7). For November 2004, the initial moisture is lower than $\theta_{s}$, 
unlike for the event of January 2006, and the rainfall intensity is too weak to initiate a significant runoff, as can be seen in Fig. 8. A comparable behaviour is observed for the event of March 2006. At the beginning of the rainfall event, no significant runoff occurs, due to a rather low value of the initial moisture $\left(\theta_{i}=0.38\right)$, compared to that of January $2005\left(\theta_{i}=\right.$ 0.43 ) and low rainfall intensity conditions. Runoff is generated when the soil moisture reaches $\theta_{i} \approx 0.44$ (Fig. 9). However, the peak-discharge is largely under-predicted. It seems that the furrows also act as a shallow drain system collecting flows from the superficial soil layer. The contribution of these interflows is all the more significant as the intensity of the rain generating direct runoff is low. This phenomenon is not taken into account in the model.

For the event of November 2004, the total rain height is low, but the rain intensity is rather large $(15 \mathrm{~mm} / \mathrm{h})$ and, in this case, the response of the furrow system is correctly simulated. This example also points out the importance of the rainfall sampling time, which is $15 \mathrm{~min}$. The rainfall distribution is unknown within this time step, and, for instance, the maximum measured value of the rainfall height $(2.4 \mathrm{~mm})$ for the event of February 2006 could have fallen in $5 \mathrm{~min}$, resulting in a precipitation rate close to $30 \mathrm{~mm} / \mathrm{h}$, which is much larger than $K_{s}$. Despite some discrepancy between the measured and simulated outflows for the events of February and March 2006 (Figs. 9 and 10), the runoff volumes are correctly simulated as shown in Fig. 11.

\subsection{Sensitivity Analysis}

A sensibility analysis is conducted on the first event (March 2005) used for model calibration (Fig. 12). One can see that $\beta$ (Fig. 12a), parameter governing soil water depletion, is much less sensitive under than above its optimal value. This highlights the role of the soil water depletion model. Peak discharge decreases by $25 \%$ when $\beta$ is multiplied by 10 . A comparable variation (Fig. 12b) is obtained when $K_{s}$ is increased by $50 \%$. Parameter $\left|h_{f}\right|$ (i.e. $\lambda_{c}$ ) appears to be much less sensitive in this case (Fig. 12c), since the value $\theta_{i}$ is close to saturation at the beginning of the simulation. One can note a strong dissymmetry regarding $n$, the roughness coefficient. Increasing $n$ by $25 \%$ results in a peak discharge decreased by $18 \%$, whereas decreasing $n$ by $25 \%$ results in a discharge peak increased by $40 \%$ (Fig. 12d).

\section{Application to drainage issues}

Water excess during winter is a constraint for the production system in the Gharb Valley irrigation system. The furrow irrigation system may facilitate the evacuation of the excessive water volumes during the winter rainfalls. The efficiency of such a system can be analyzed under typical rainfalls, such as events of one-year return period. These events are characterized by significant rainfall intensities and should be correctly simulated with the present model.

As an illustration, a typical rainfall is generated thanks to the method proposed in the French national flood synthesis in 1981 for an event of a one-year return period. The method uses the coefficients of the Montana formula. The latter gives the rainfall intensity as a function of time $\left(q_{r}=a t^{-b}\right)$ for a given return period characterized by specific values of $a$ and $b$. The values $a=35 \mathrm{~mm} / \mathrm{h}$ and $b=0.6$ for a one-year return period were obtained by Hammani (2002) for the Gharb region. A characteristic time $D$ is defined (the lag-time in the case of a watershed), generally set to the time between the maximum rainfall intensity and the peak discharge of a representative event. For a time $\tau$ between $-D$ and $D$, the rain intensity is defined as follows: 


$$
q_{r}(\tau)=\frac{a(1-b)}{14 \tau^{b}} \frac{\left(\frac{\tau}{D}\right)^{2}+20 \frac{D}{|\tau|}-14}{\left[\left(\frac{\tau}{D}\right)^{2}+2 \frac{D}{|\tau|}-2\right]^{\frac{10-3 b}{7}}} .
$$

The cumulative rainfall between $-\tau$ and $+\tau$ is given by:

$$
P_{1}(-\tau, \tau)=a\left[\frac{\tau}{\left[\left(\frac{\tau}{D}\right)^{2}+2 \frac{D}{\tau}+2\right]^{3 / 7}}\right]^{1-b} \text {. }
$$

The value of $D$ corresponding to the highest observed discharges (March 2005, January 2006) is close to $0.75 \mathrm{~h}$. In order to generate a complex rainfall, the synthetic hyetograph is assumed to be preceded by moderate rainfalls (Fig. 13) filling progressively the soil water reserve as for the event of March 2005. Two different initial moisture values were used $\left(\theta_{i}=0.35\right.$ and $\theta_{i}$ $=0.40$ ). This example shows that, even when the simulation starts with $\theta_{i}$ far from saturation, an intense rainy event generate a substantial runoff.

Depending on initial soil conditions, a peak discharge in the range of 22 to $35 \mathrm{~L} \mathrm{~s}^{-1}$ $\mathrm{ha}^{-1}$ can be reached. In the experimental plot, the evacuation system consists of trapezoidal ditches with a bottom width of $50 \mathrm{~cm}$, a maximal depth of $25 \mathrm{~cm}$, a side slope of 0.5 and a bottom slope of $0.2 \%$. A Manning roughness coefficient of 0.05 leads to a conveyance capacity of $39 \mathrm{~L} / \mathrm{s}$. This conveyance capacity allows the one year return simulated event to be evacuated whatever the value of the initial moisture be. However, in the Gharb Valley, the previous ditch characteristics are designed to collect the runoff of plot groups of 6 hectares, and then most ditches have a largely insufficient conveyance capacity. Even if the furrow system is efficient to evacuate water from the plots, this excessive water should be conveyed out of the cropped lands; the present modelling approach can be used to design such an evacuation system.

\section{Conclusion}

This paper analyzed the behaviour of a furrow system under complex rainfall events. A numerical model was developed, combining the kinematic wave solution for the water transfer through the furrow system and a production function based on the Green-Ampt equation. The model was used to evaluate peak discharge and water amounts that can be evacuated from plots of approximately 1 ha. A calculation procedure was developed to account for complex rainfall events.

The model was calibrated using flow measurements obtained during irrigation events and five rainfall events in 2005 and 2006. The soil parameters obtained during the irrigation events give satisfactory results when applied to the simulation of rainfall events. The parameter used in the flow propagation (the Manning roughness coefficient) within the furrows needs to be calibrated separately under irrigation and rainfall, since the flow characteristics are largely different. In the validation process, the model showed some limitations in the case of small rainfall intensities. These limitations may be addressed by adopting shorter sampling times for the rainfall monitoring, and by representing the interflows which may become significant when rain intensities are low.

As an application, the model was used to simulate the behaviour of the furrow system under a one-year return period rainfall. The results provide the peak discharge that should be 
evacuated out of a parcel or a group of parcels, and therefore can be used to design ditches able to drain the excessive volumes of water out of the cropped area during a rainy period.

\section{Appendix: calculation of the derivatives $\mathrm{d} A / \mathrm{d} Y$ and $\mathrm{d} Q / \mathrm{d} Y$}

In a cross section, assumed trapezoidal, water depth is denoted $Y$, bottom width is denoted $B$ and side slope is denoted $m$. The wetted area is given by:

$$
A=(B+m Y) \mathrm{Y} \text {. }
$$

The derivation $A^{\prime}=\mathrm{d} A / \mathrm{d} Y$ is straightforward:

$$
A^{\prime}=B+2 m Y \text {. }
$$

The wetted perimeter $P$ is given by:

$$
P=B+2 \sigma Y
$$

where $\sigma=\left(1+m^{2}\right)^{1 / 2}$ and the hydraulic radius $R_{h}=A / P$. From Eq. (10b), one gets $Q$ as a function of $Y$ :

$$
Q=\frac{A}{n} R_{h}^{2 / 3} \sqrt{S_{0}}=\frac{1}{n}\left(B Y+m Y^{2}\right)^{5 / 3}(B+2 \sigma Y)^{-2 / 3} \sqrt{S_{0}}
$$

and then its derivative $Q^{\prime}=\mathrm{d} Q / \mathrm{d} Y$ :

$$
Q^{\prime}=\frac{\sqrt{S_{0}}}{3 n}\left[5(B+2 m Y)\left(\frac{B Y+m Y^{2}}{B+2 \sigma Y}\right)^{2 / 3}-4 \sigma\left(\frac{B Y+m Y^{2}}{B+2 \sigma Y}\right)^{5 / 3}\right] .
$$

After a few algebraic manipulations, one gets:

$$
Q^{\prime}=\frac{\sqrt{S_{0}}}{3 n}\left(\frac{B Y+m Y^{2}}{B+2 \sigma Y}\right)^{2 / 3}\left[\frac{5 B^{2}+6 B \sigma Y+10 B m Y+16 m \sigma Y^{2}}{B+2 \sigma Y}\right] .
$$

\section{References}

ASCE, 1993. Task committee on definition of watershed models of the watershed management committee. Irrig. and Drain. Div. Criteria for evaluation of watershed models. J. Irrig. and Drain. Eng., ASCE 119(3): 429-442.

Bouarfa S., Zimmer D., 2000. Water table shapes and drain flow rates in shallow drainage systems. J. Hydrol., 235: 264-275.

Chow V.T, Ben-Zvi, A. 1973. Hydrodynamic modelling of two dimensional water flow. J. Hydrau.. Div., ASCE. HY 99(11): 2023-2040.

Chu S.T., 1978. Infiltration during unsteady rain. Water Resour. Res. 14(3): 461-466.

Cunge J.A., Holly F.M., Vervey A., 1980. Practical aspects of computational river hydraulics. Pitman Ltd.

Esteves M., Faucher X., Galle S., Vauclin M., 2000. Overland flow and infiltration for small plots during unsteady rain: numerical results versus observed values. J. .Hydrol. 228: $265-282$.

Gardner W.R., 1958. Some steady state solutions of the unsaturated moisture flow equation. Soil Sci. 85: 228-232.

Green W. H, Ampt G.. A., 1911. Studies in soil physics I. The flow of air and water through soil. J. Agric. Sci., 4: 1-24.

Hammani A., 2002. Modélisation couplée du drainage souterrain et du drainage de surface: Application à la conception du drainage agricole dans le périmètre irrigué du Gharb (Maroc). Ph.D. thesis. ENGREF, France. 241 p.

Heasom, W., Traver, R.G., Welker, A., 2006. Hyrologic modelling of a bioinfiltration best management practice. JAWRA 42(5): 1329-1347.

Kutilek M, Nielsen R. (1994). Soil hydrology. Geoscience Publisher, Cremlingen-Destedt 
Author-produced version of the article published in Agricultural Water Management, 2009, 96 (7),1128-1136. The original publication is available at http://www.sciencedirect.com/science/article/pii/S0378377409000596 doi:10.1016/j.agwat.2009.02.014

Catena-Verlag, Germany, Chap. 5.3.2.: 104-112.

Mailhol J.C, Gonzalez J.M., 1993. A furrow irrigation model for real time applications on cracking soils - J. Irrig. and Drain., ASCE, Vol 119(5): 768-783.

Mailhol J.C., Priol M, Benali M., 1999. A furrow irrigation model to improve irrigation practices in the Gharb valley of Moroco. Agric. Water Manag. . 1475: 1-17

Mailhol J.C., 2003. A predictive form of Horton's equation for simulating furrow irrigation. J. Irrig. and Drain. Eng., ASCE, 129 (6): 412-421.

Mailhol J.C., Ruelle P. , Popova Z., (2005).' SOFIP: A field-scale modelling of water management and crop yield for furrow irrigation. Irrig. Sci. 24: 37-48.

Mailhol J.C., A., Merot A., 2008. SPFC : a tool to improve water management and hay production in the Crau region. Irrig. Sci. 26(4): 289-302

Marcesse, J., 1967. Détermination de la capacité de rétention d'un sol au moyen de l'humidimètre à neutron. I.A.E.A. Symposium, Istanbul: 138-144.

Mein R.G., Larson, C., 1973. Modeling infiltration during a steady rain. Water Resour. Res., 9: 2384-394.

Muños-Carpena R., Parsons J.E., Gilliam J.W., 1998. Modelling hydrology and sediment transport in vegetative filter strips. J. Hydrol., 214: 111-129.

Newman S.P., 1976. Wetting front pressure head in the infiltration model of Green and Ampt Water Resour. Res. 12: 564-566.

Paige G.B., Stone J.J., Guertin D.P, Lane L.L., 2002. A strip model approach to parameterize a coupled Green -Ampt kinematic wave model. J. Am. Water Resour. Assoc.Vol. 38 (5): 1363-1377.

Philip J.R., 1957. The theory of infiltration I. Sorptivity and algebraic infiltration equation. Soil Sci. 83: 345-357.

Philip J.R., 1973. On solving the unsaturated flow equation. 1. The flux-concentration dependent relation. Soil Sci. 116: 328-335.

Philip J.R., 1984. Steady infiltration from circular cylindrical cavities. Soil Sci. Am. J. , 48(5): 270-278.

Quinones H., Ruelle P, Nemeth I., 2003. Comparison of three calibration procedures for TDR soil moisture sensors. Irrig. and Drain. 52: 203-217.

Rayej, M., Wallender, W.W, 1985. Furrow irrigation time reduction. J. Irrig. Drain. Eng., ASCE , 111(2)

Swartzendruber, D., 1974. Infiltration of constant flux-rainfall into soil as analyzed by the approach of Green and Ampt. Soil Sci. 117: 272-281.

Taky A., Mailhol J.C., Debbarh, Bouarfa S., Hammani A., Zimmer D., Ruelle P., Belhabes K, 2005. Diagnostic des pratiques d'irrigation gravitaire et possibilités d'amélioration dans le Gharb au Maroc. Actes du séminaire Euro-Méditerranéen sur la modernisation de l'agriculture irriguée Tome 1: 32-45, (205/2481 ISBN : 9954-447-05-9).

Taylor, G., Kavvas. M.L. Govindaraju R.S., Storm D.E., 1993. Applicability of StVenant equations for two dimensional overland flow over rough infiltration surfaces. J Hydraul. Eng, ASCE. 119(1): 51-43.

Thony J.L., Vachaud, G., Clothier, B.E., Angulo-Jaramillo R., 1991. Field measurement of the hydraulic properties of soil. Soil Technology, 4: 111-113.

Wahl, T. L., Clemmens, A. J., Replogle, J. A., Bos, M. G., 2005. Simplified design of flumes and weirs. Irrigation and Drainage, 54: 231-247.

Walker WR., Humpherys A.S., 1983. Kinematic wave furrow irrigation model. J. Irrig. Drain. Eng. ASCE, 116(3): 299-318.

White I., Sully J., 1987. Macroscopic and microscopic capillarity length and timescale from field infiltration. Water Resour. Res., 23: 1514-1522. 
Woodhiser, D.A, Liggett, J.A., 1967. Unsteady, one-dimensional flow over a plane: the rising hydrograph, Water Resour. Res. 3(3): 753-771.

Zhang W., Cundy, T.W., 1989. Modelling of two dimensional overland flow. Water resour. Res. 25(9): 2019-2035. 
Author-produced version of the article published in Agricultural Water Management, 2009, 96 (7),1128-1136. The original publication is available at http://www.sciencedirect.com/science/article/pii/S0378377409000596 doi:10.1016/j.agwat.2009.02.014
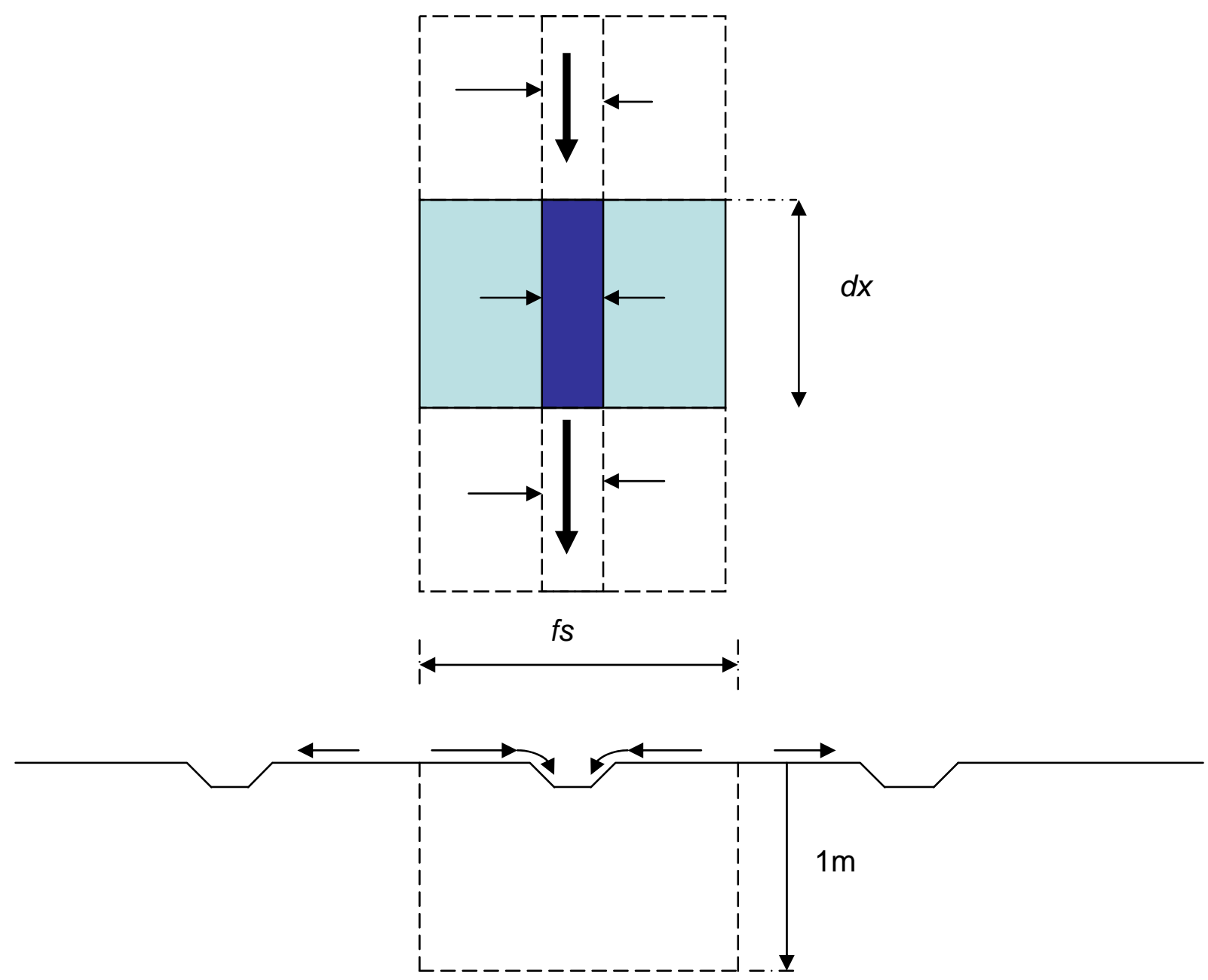

Fig. 1. Overview of the infiltration-runoff process at the scale of an elementary sub-plot 
Author-produced version of the article published in Agricultural Water Management, 2009, 96 (7),1128-1136. The original publication is available at http://www.sciencedirect.com/science/article/pii/S0378377409000596 doi:10.1016/j.agwat.2009.02.014

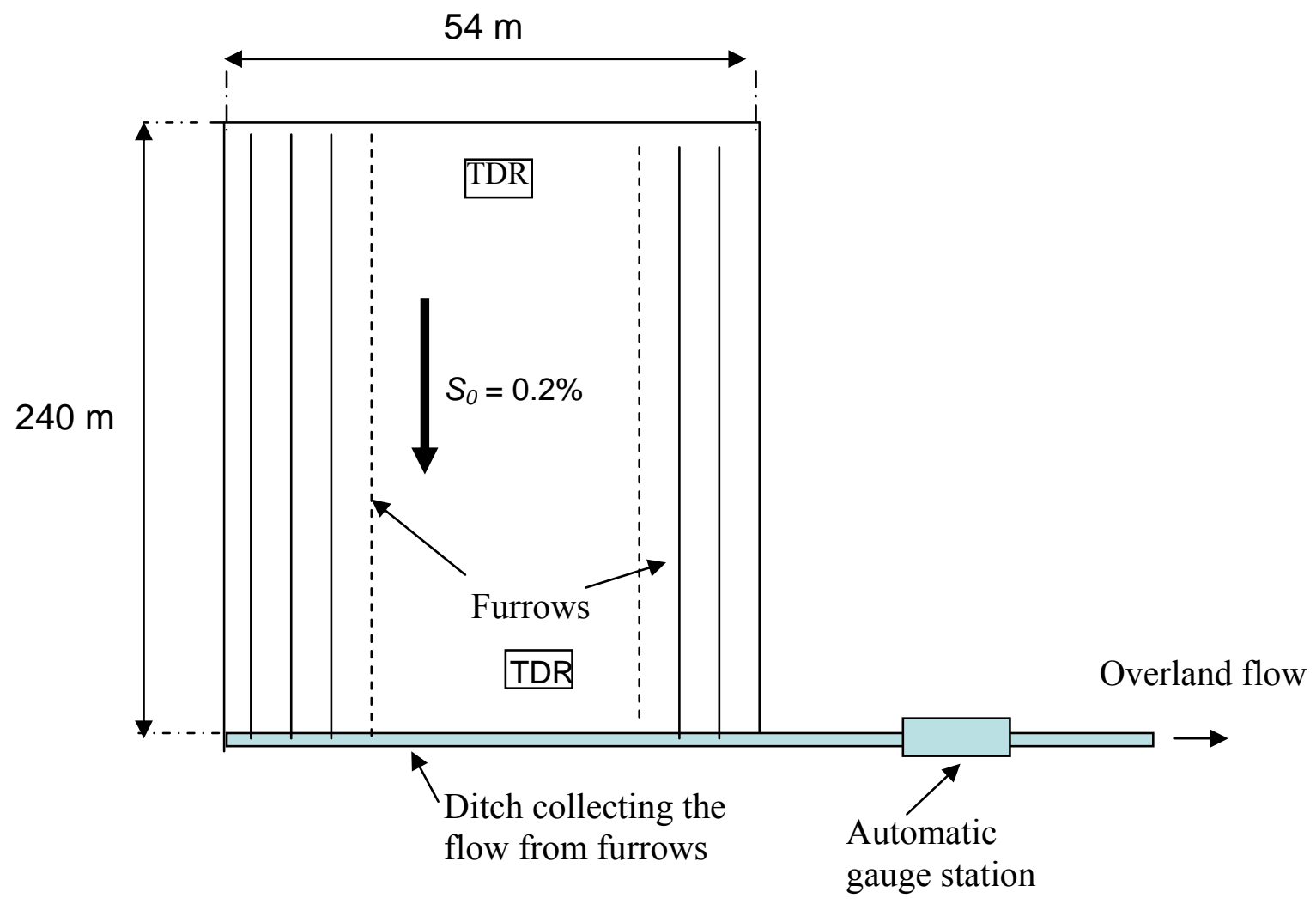

Fig. 2. Overview of the plot during the winter period 

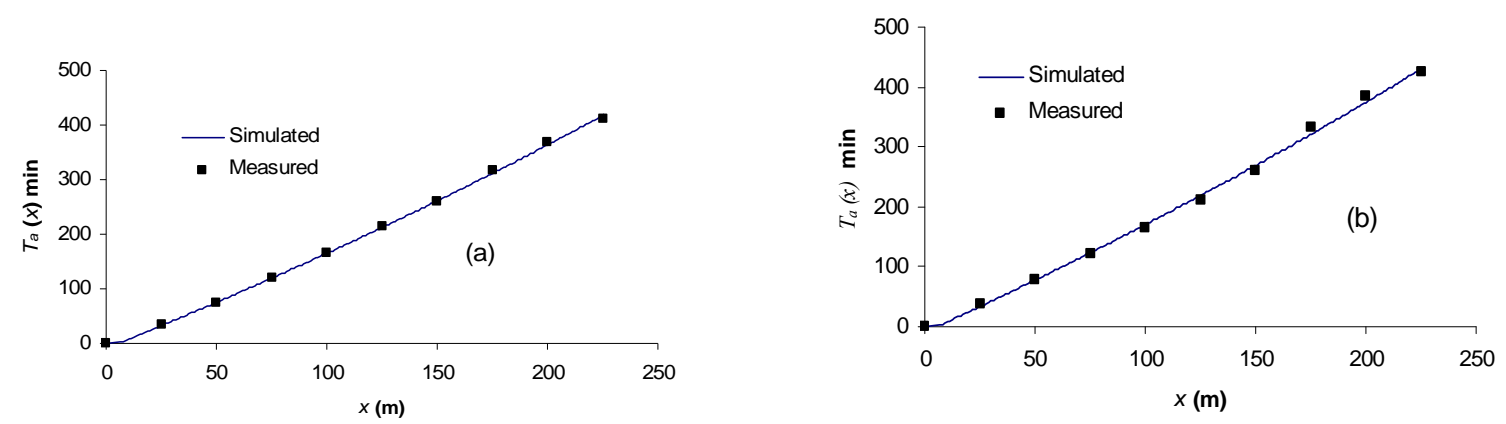

Fig. 3. Calibration of $\lambda_{c}$ and $K_{s}$ on the median furrow for the $3^{\text {rd }}$ irrigation event (a) and validation on the $6^{\text {th }}$ irrigation event (b) of 2005. 
Author-produced version of the article published in Agricultural Water Management, 2009, 96 (7),1128-1136. The original publication is available at http://www.sciencedirect.com/science/article/pii/S0378377409000596 doi:10.1016/j.agwat.2009.02.014

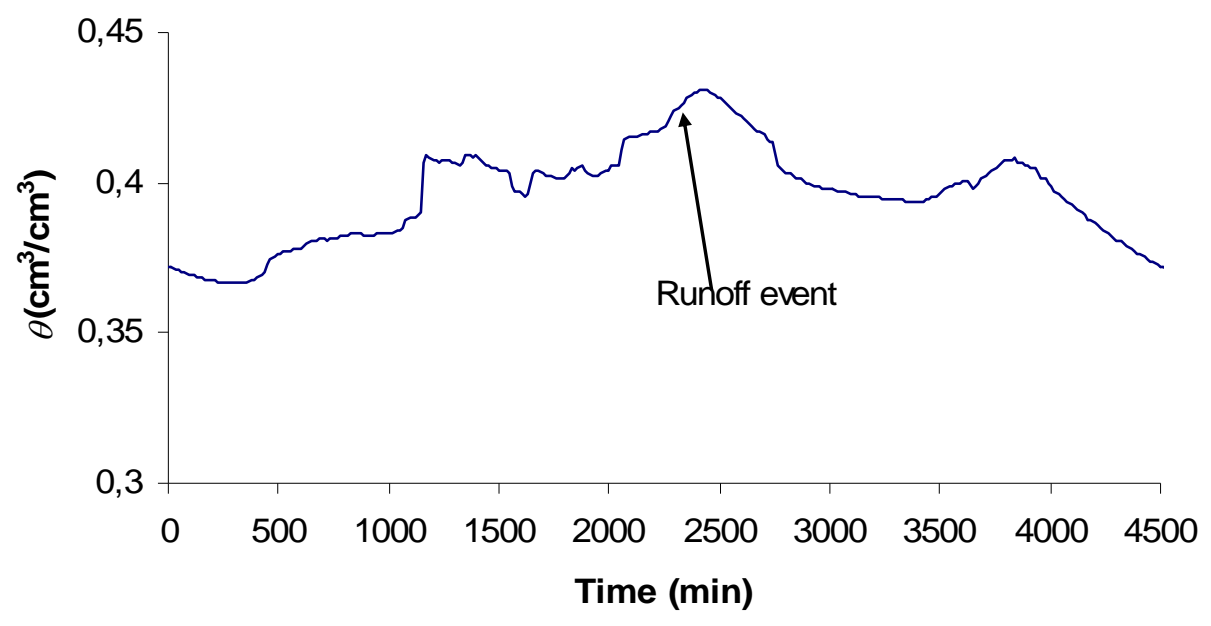

Fig. 4. Evolution of volumetric water content measured by TDR (averaged values of the two sites) from $03 / 03$ at $0 \mathrm{~h} \mathrm{AM}$ to $03 / 06$ at $3.00 \mathrm{AM}$ in 2005. 
Author-produced version of the article published in Agricultural Water Management, 2009, 96 (7),1128-1136. The original publication is available at http://www.sciencedirect.com/science/article/pii/S0378377409000596 doi:10.1016/j.agwat.2009.02.014

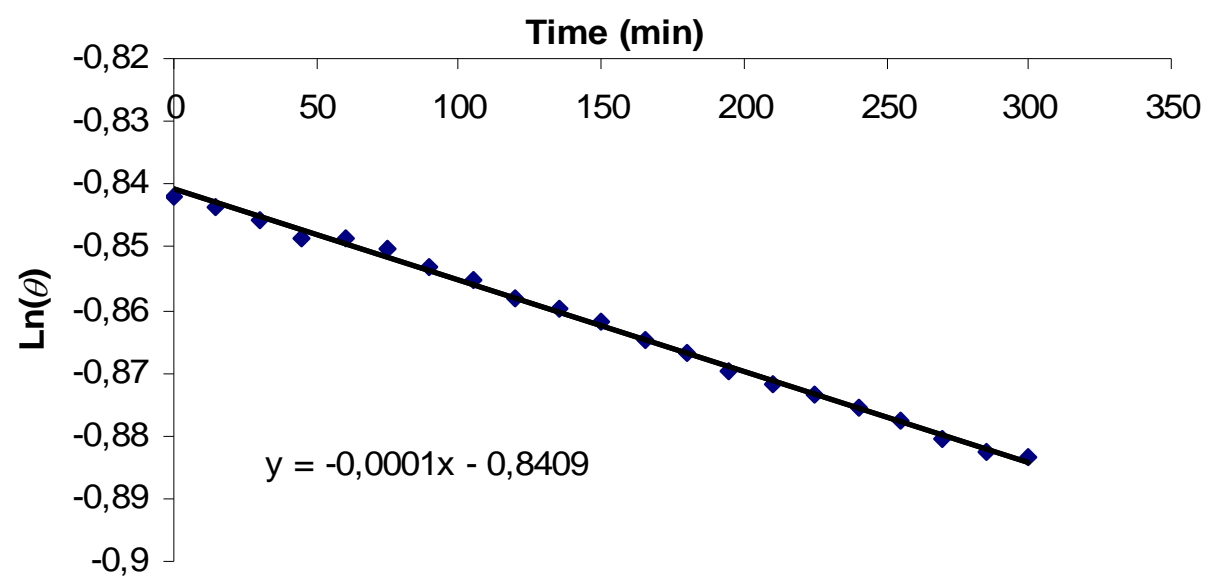

Fig. 5. Graphical calibration of $\beta$ involved in Eq. (9) from the runoff event of March the $4^{\text {th }}$ in 2005 . 
Author-produced version of the article published in Agricultural Water Management, 2009, 96 (7),1128-1136. The original publication is available at http://www.sciencedirect.com/science/article/pii/S0378377409000596 doi:10.1016/j.agwat.2009.02.014

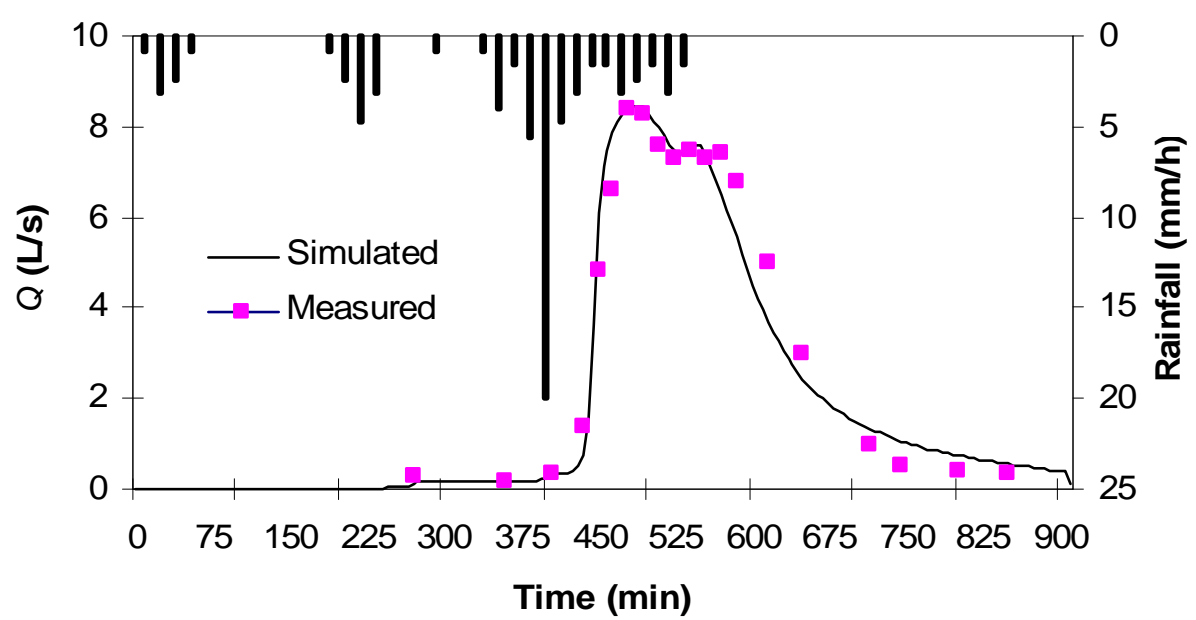

Fig. 6. Model calibration on the event of March $2005\left(K s=0.2 \mathrm{~cm} / \mathrm{h}, n=0.2, \theta_{l}=0.43 ; C E\right.$ $=0.965)$. Measured rainfall on a $15 \mathrm{~min}$ time step is converted here in $\mathrm{mm} / \mathrm{h}$. 
Author-produced version of the article published in Agricultural Water Management, 2009, 96 (7),1128-1136. The original publication is available at http://www.sciencedirect.com/science/article/pii/S0378377409000596 doi:10.1016/j.agwat.2009.02.014

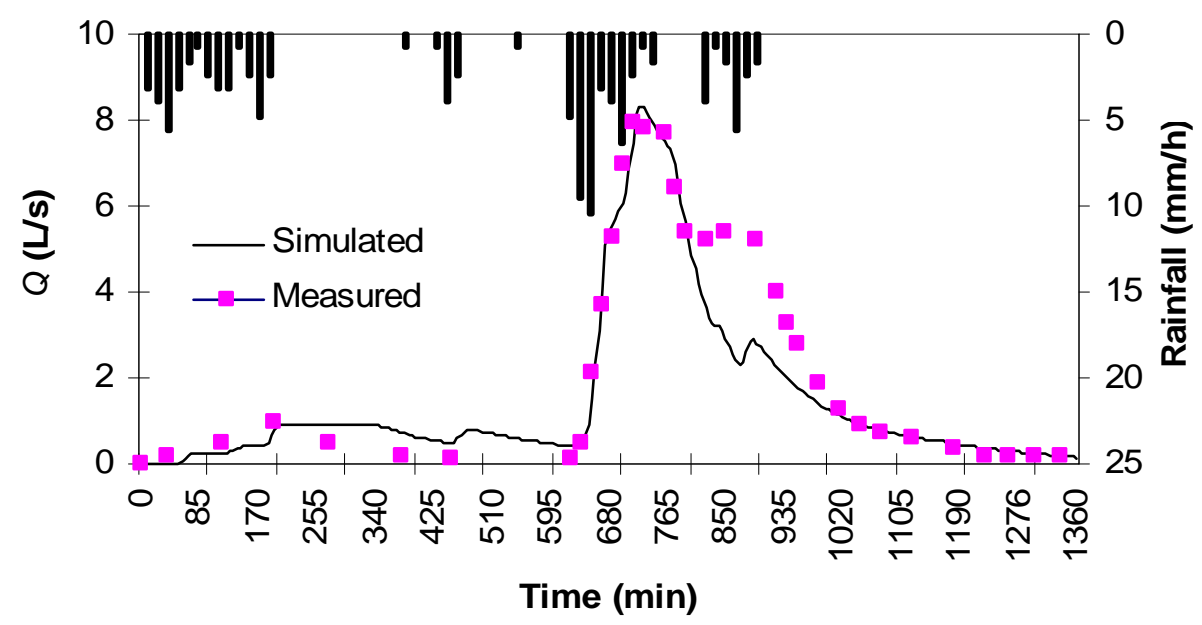

Fig. 7. Model verification on the event of January 2006: $\left(K s=0.2 \mathrm{~cm} / \mathrm{h} ; n=0.2, \theta_{l}=0.43\right.$; $C E=0.889)$ 


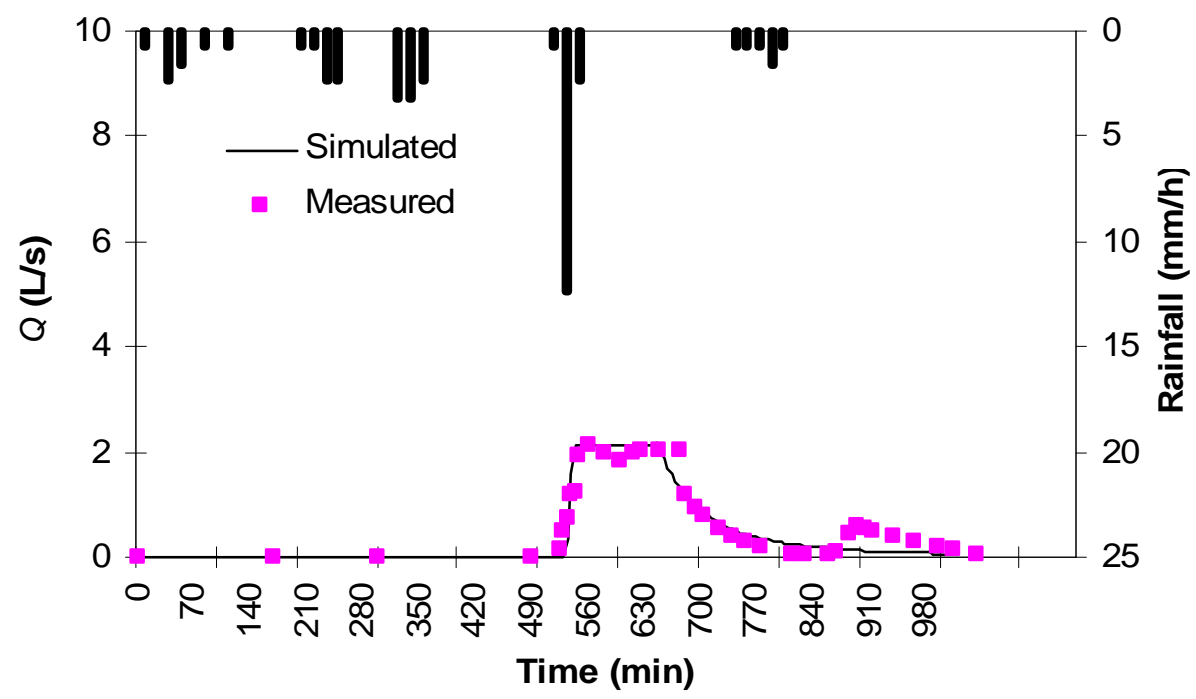

Fig. 8. Model verification on the event of November $2004(\theta i=0.40 ; C E=0.829)$ 
Author-produced version of the article published in Agricultural Water Management, 2009, 96 (7),1128-1136. The original publication is available at http://www.sciencedirect.com/science/article/pii/S0378377409000596 doi:10.1016/j.agwat.2009.02.014

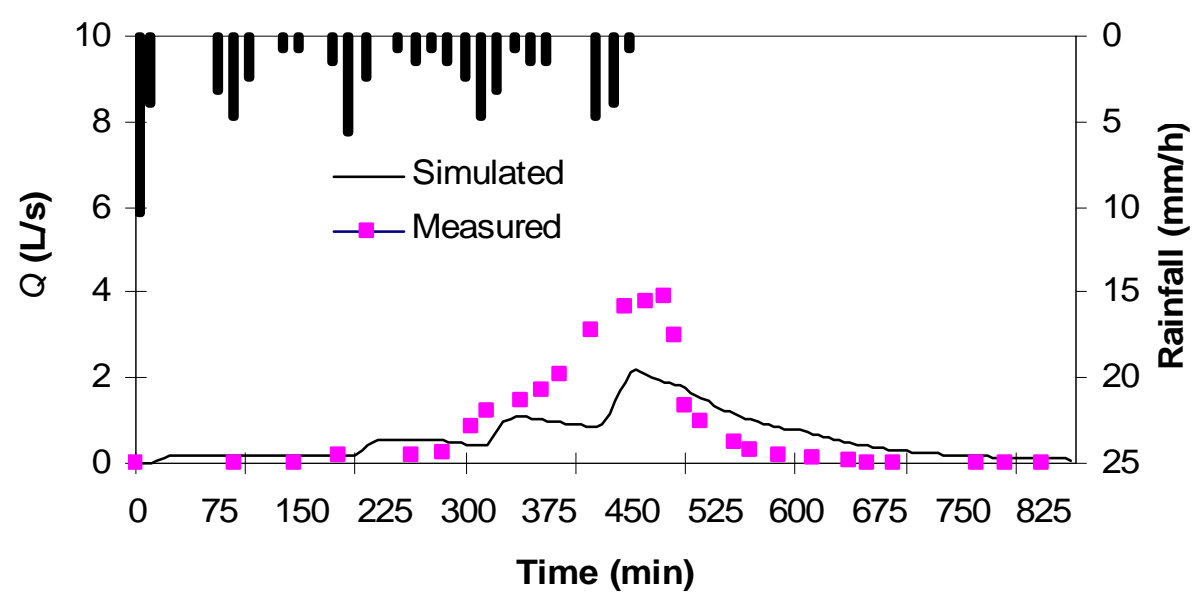

Fig. 9. Model verification on the event of March $2006(\theta i=0.38 ; C E=0.501)$ 
Author-produced version of the article published in Agricultural Water Management, 2009, 96 (7),1128-1136. The original publication is available at http://www.sciencedirect.com/science/article/pii/S0378377409000596 doi:10.1016/j.agwat.2009.02.014

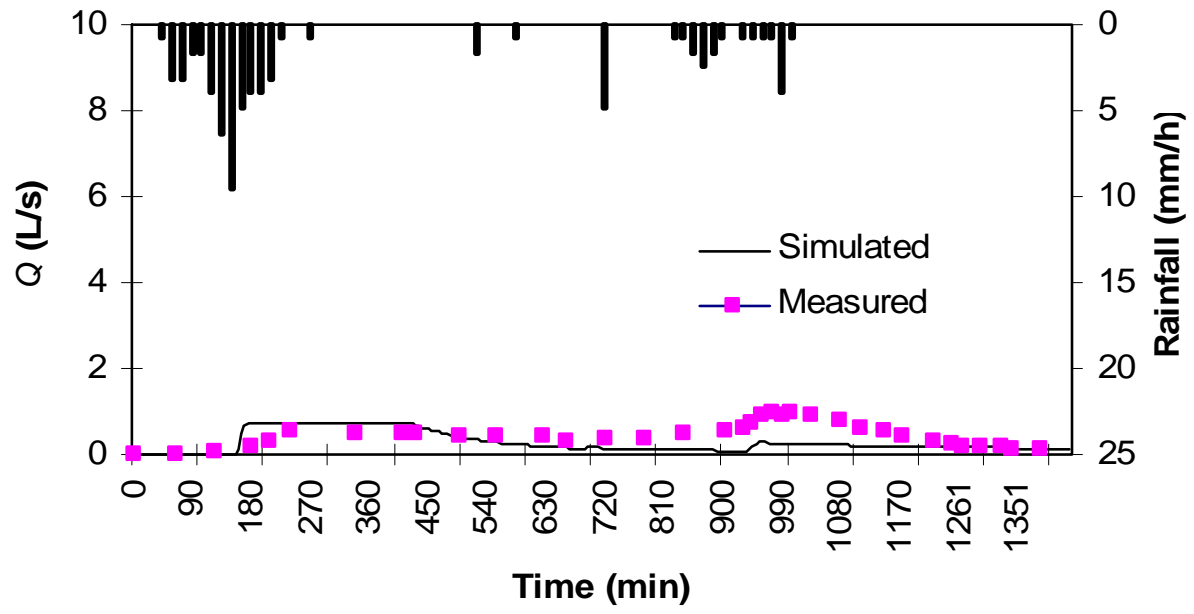

Fig. 10. Model verification on the event of February $2006(\theta i=0.42 ; C E=-1.1)$ 


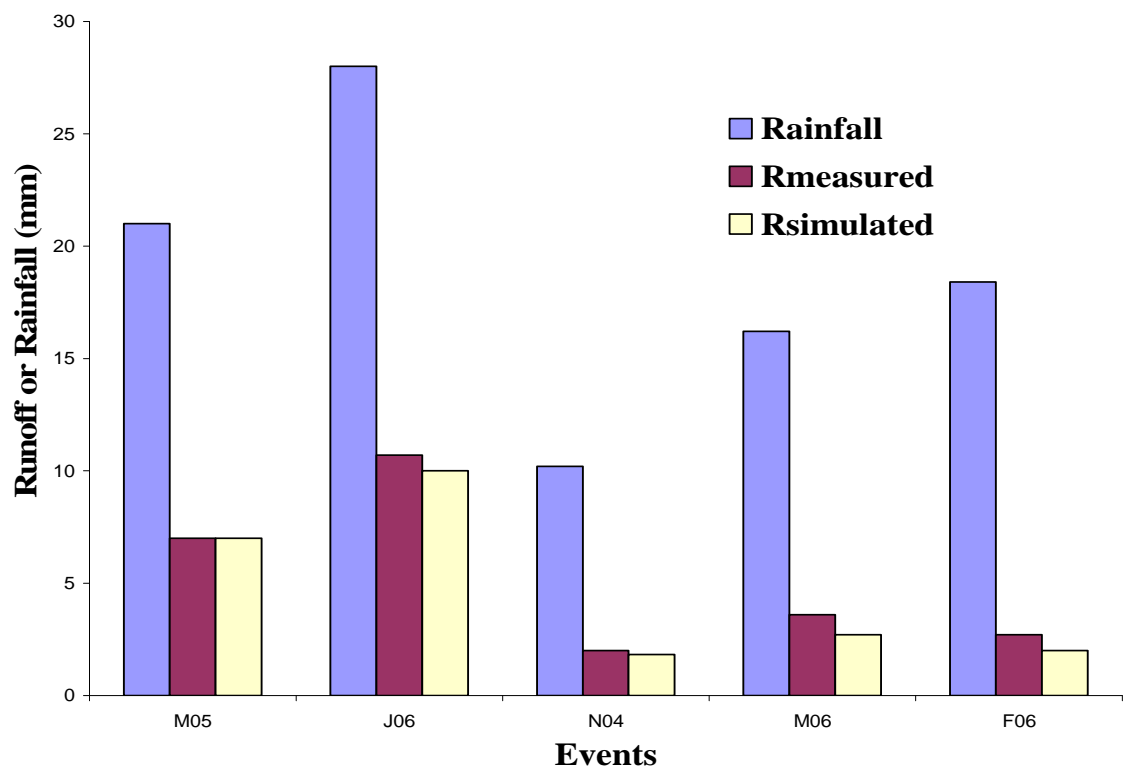

Fig. 11. Measured and simulated runoff amount for the different rainfall events shown in Figs 6-10. 

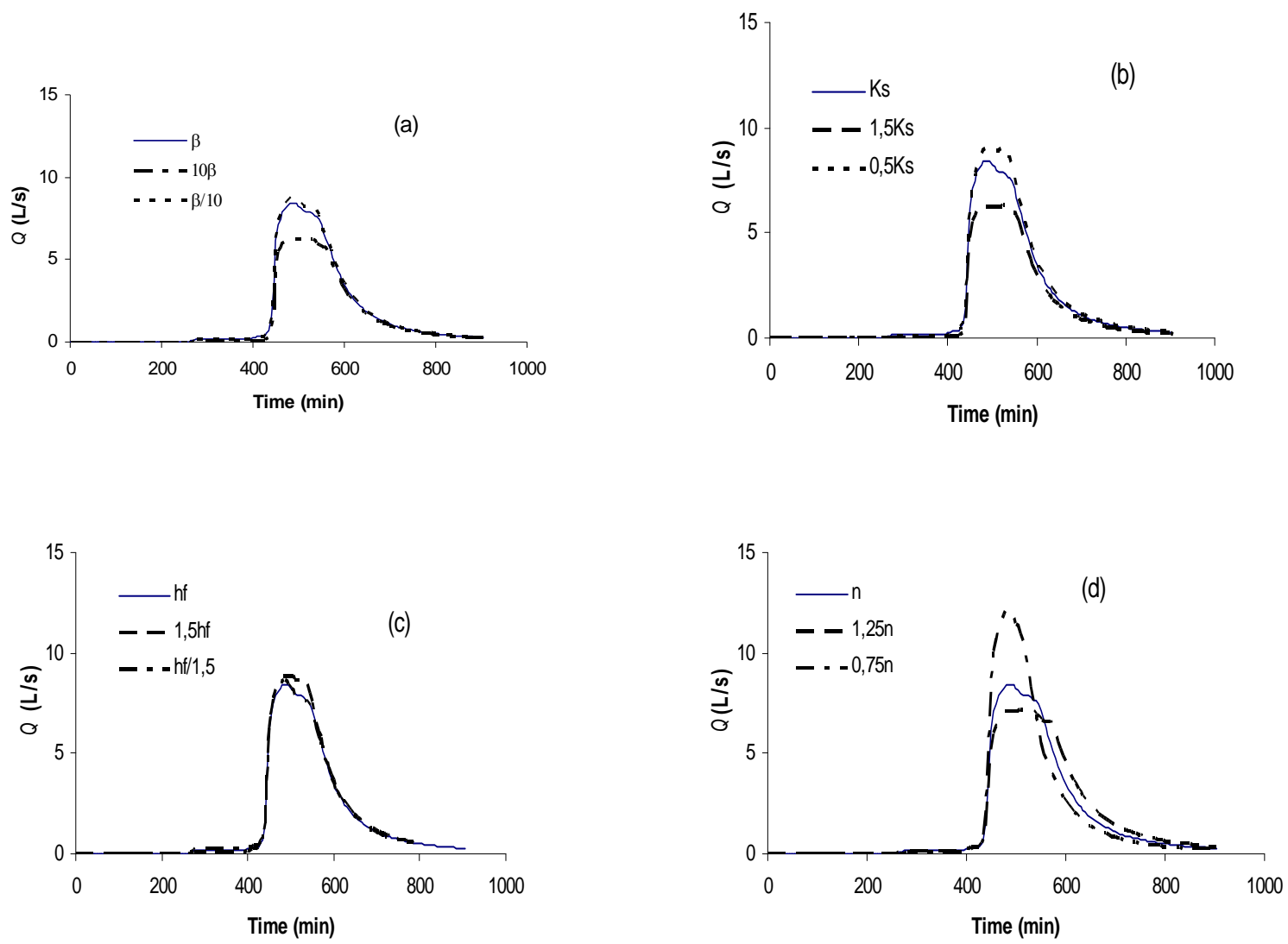

Fig. 12. Sensitivity analysis of the model parameters on the event of March 2005: (a): $\beta$, (b):Ks, (c): $h_{f},(\mathrm{~d}): n$. 
Author-produced version of the article published in Agricultural Water Management, 2009, 96 (7),1128-1136. The original publication is available at http://www.sciencedirect.com/science/article/pii/S0378377409000596 doi:10.1016/j.agwat.2009.02.014

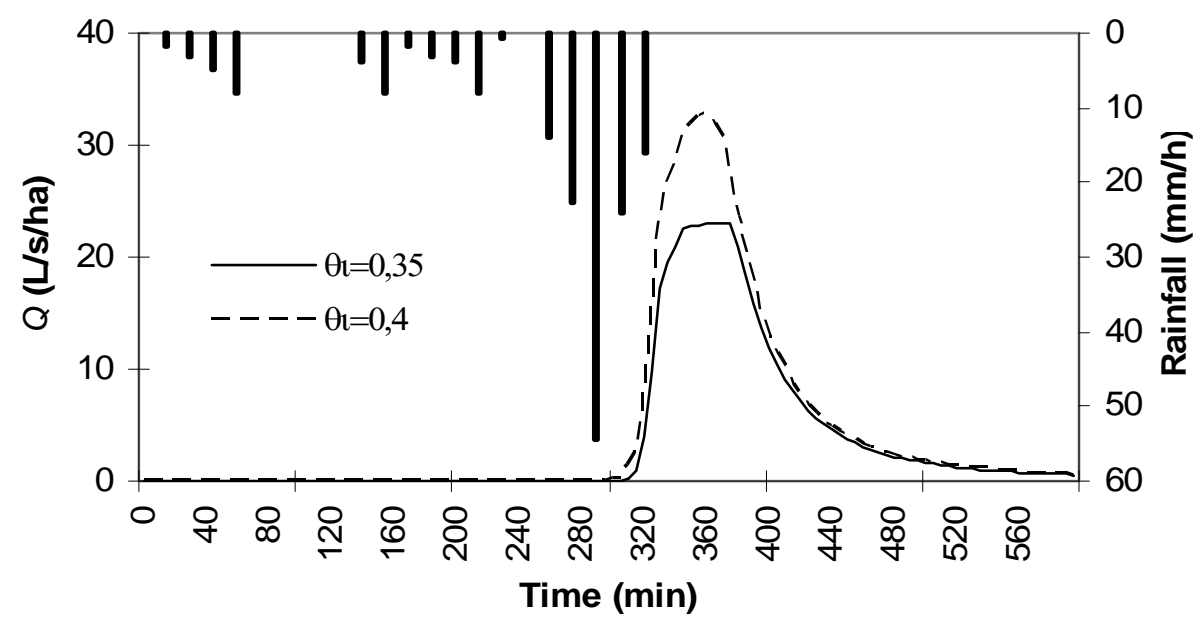

Fig. 13. Runoff event generated by a synthetic hyetograph (return period $=1$ year) for different initial soil water contents. 